\title{
Kebijakan Perlindungan Tenaga Kesehatan dalam Menghadapi Coronavirus Disease 2019 (COVID-19) di Indonesia
}

\author{
Policies to Protect Health Workers during Coronavirus Disease 2019 \\ (COVID-19) Pandemic in Indonesia
}

\author{
Christa Gumanti Manik ${ }^{1}$, Sri Mardikani Nugraha ${ }^{1}$, Maya Ryandita ${ }^{2}$ \\ 1) Pusat Penelitian dan Pengembangan Sumber Daya dan Pelayanan Kesehatan, Jalan Percetakan Negara No. 29 Jakarta \\ 10560 , Indonesia \\ ${ }^{2)}$ Social Protection Hub, Grand Kebon Sirih, Jalan Kebon Sirih No. 35 Jakarta 10340, Indonesia \\ Korespondensi: christamanik30@gmail.com
}

Submitted: 29 Mei 2020, Revised: 20 Juli 2020, Accepted: 12 Agustus 2020

https://doi.org/10.22435/jpppk.v4i2.3274

\begin{abstract}
Abstrak
Tenaga kesehatan (nakes) dalam penanganan pandemi Coronavirus Disease (COVID-19) menghadapi berbagai isu, seperti kekurangan Alat Pelindung Diri (APD), kelelahan fisik, tekanan psikososial karena stigmatisasi dan diskriminasi. Mengingat pentingnya peran nakes dalam sistem kesehatan, khususnya terkait penanganan COVID-19, penulisan ini bertujuan untuk menganalisis kebijakan perlindungan nakes pada saat pandemi COVID-19, dengan menelaah regulasi, jurnal terkait, media (elektronik) nasional dan internasional, serta data nakes yang menangani, terinfeksi, dan meninggal karena COVID-19. Segitiga kebijakan Waltz dan Gilson digunakan dalam menganalisis kebijakan. Kebijakan yang telah ditetapkan pemerintah pusat antara lain terkait dengan relaksasi kebijakan dalam memenuhi ketersediaan APD, insentif, penyediaan transportasi dan penginapan, telemedicine, kewajiban penggunaan masker, dan layanan psikososial berupa buku pedoman dan konseling online. Permasalahan yang ada terkait kebijakan tersebut seperti pengawasan kualitas APD donasi masih berada di level rumah sakit, insentif finansial untuk nakes hanya sampai tiga bulan, telemedicine menuai pro dan kontra dalam penegakan diagnosis penyakit, dan layanan psikososial berupa konseling online dan buku pedoman masih bersifat umum. Pemerintah perlu mengawasi ketersediaan APD yang berkualitas. Diperlukan insentif finansial yang berkelanjutan sampai wabah berakhir dan insentif nonfinansial seperti memberlakukan paid sick leave, mengatur jumlah jam kerja yang tepat, serta menyediakan layanan psikososial yang ditujukan khusus untuk nakes dan meningkatkan penyebaran informasi layanan psikososial tersebut. Diperlukan pelatihan berkelanjutan dalam merespon wabah dan kerjasama multisektoral dalam pengembangan layanan kesehatan berbasis teknologi. Pemerintah perlu menghimpun data nasional nakes yang terinfeksi maupun meninggal. Pemakaian masker dan Perilaku Hidup Bersih dan Sehat (PHBS) harus menjadi budaya dikalangan masyarakat.
\end{abstract}

Kata kunci : Kebijakan, Tenaga Kesehatan (Nakes), Coronavirus Disease 2019 (COVID-19)

\section{Abstract}

Health workers battling Coronavirus Disease (COVID-19) outbreak face various issues, such as lack of Personal Protective Equipment (PPE), physical fatigue, and psychosocial pressures. Considering the health workers' significant role in the health system, this paper aims to analyse Indonesian government's policies related to the protection of health workers during the COVID-19 outbreak, by examining regulations, related journals, national and international (electronic) media, and related data on health workers contracting the disease. Waltz and Gilson's policy triangle was used for the policies analysis. Government's policies related to the protection of health workers involve easing policies to meet PPE demands, providing financial incentives, providing online psychosocial services, transportation, and hotel, using telemedicine, and wearing masks in public spaces. 
Issues related to the policies include lack of quality monitoring for donated PPE, the financial incentives for health workers which are only for three months, and the use of telemedicine which is still debatable. We suggest that government needs to monitor the availability of high-quality PPE, arrange appropriate working hours for health workers, provides the financial incentives at least until the outbreak ends, as well as provides non-financial incentives, such as paid sick leave and psychosocial services specialy intended for health workers. Multisectoral cooperation to develop technology-based health services and continued training for health workers in responding the outbreak are needed. Government needs to collect and publish data on health worker infection rates and deaths nationally. It is also important to keep promoting the use of masks and good hygiene practices in the society.

Keywords: Policy, Health Workers, Coronavirus Disease 2019 (COVID-19)

\section{Pendahuluan}

Wabah Novel Coronavirus Disease 2019 (COVID-19) telah menyebar cepat hampir ke seluruh dunia. Sejak kasus pertama ditemukan di Kota Wuhan, Provinsi Hubei, Cina pada tanggal 31 Desember 2020, kemudian menyebar ke seluruh dunia termasuk Indonesia. Pada tanggal 11 Maret 2020, World Health Organization (WHO) menetapkan COVID-19 sebagai Global Pandemic. ${ }^{1}$ Kemudian pada tanggal 13 April 2020 (Gambar 1), Pemerintah Indonesia melalui Badan Nasional Penanggulangan Bencana (BNPB) menetapkan COVID-19 sebagai bencana nasional, dengan Keputusan Presiden (Kepres) RI No 12 Tahun 2020 tentang Penetapan Bencana Non-Alam Penyebaran COVID-19 sebagai Bencana Nasional. Jumlah masyarakat terinfeksi COVID-19 pun terus bertambah, per tanggal 13 Mei 2020 pukul 12.00 WIB, sebanyak 15.438 orang kasus positif, 1.028 orang $(6,7 \%)$ meninggal dan $3.287(21,2 \%)$ orang dinyatakan sembuh. ${ }^{2}$
Pembangunan kesehatan tidak lepas dari kontribusi tenaga kesehatan (nakes), di mana nakes memberikan kontribusi $80 \%$ dalam pembangunan kesehatan. $^{3}$ Belajar dari kasus MERS dan SARS, angka infeksi pada tenaga medis sebesar 18,6\%, sedangkan pada kasus SARS angka infeksi nakes $21 \%$, dengan penyebab penularan melalui penggunaan nebulizer, endotracheal suction, intubation, cardiopulmonary resuscitation, pemberian makan melalui nasogastric tube, dan oksigen. ${ }^{4}$

WHO mengonfirmasi pada tahun 2002 dari 8.098 kasus, pekerja layanan kesehatan menyumbang 1.707 (21\%) kasus, ${ }^{5}$ seperti Middle East Respiratory Syndrome (MERS) dan Severe Acute Respiratory Syndrome (SARS), virus penyebab COVID-19 dapat ditransmisikan melalui kontak erat antar orang dari percikan (droplet) dan transmisi aerosol dapat terjadi pada saat melakukan prosedur medis dan perawatan dukungan seperti intubasi trakea, ventilasi non-invasif, trakeotomi,

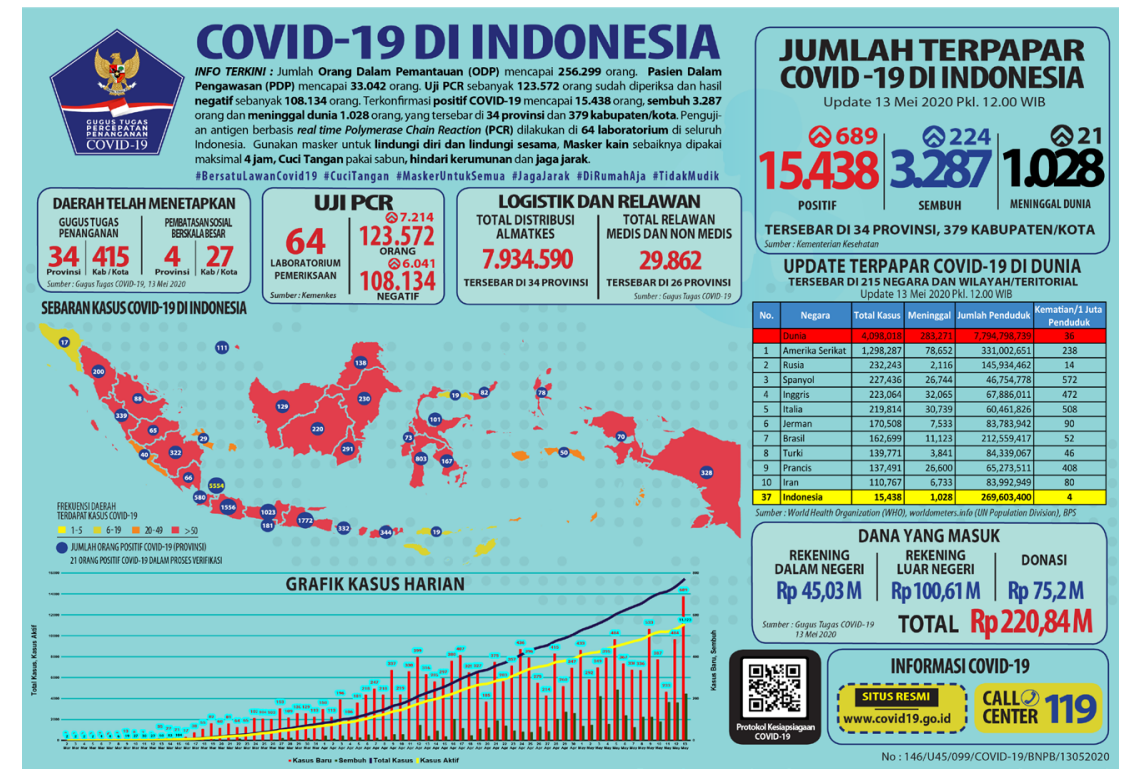

Gambar 1. Infografis COVID-19 (update 13 Mei 2020) 
resusitasi jantung paru, ventilasi manual sebelum intubasi, bronkoskopi. ${ }^{6}$ Nakes berada di garis depan dalam menangani pandemi COVID-19 dan berisiko tinggi terpapar infeksi. WHO pada laporannya per 8 April 2020 menyatakan lebih dari 22.000 petugas kesehatan di 52 negara dan wilayah terinfeksi COVID-19. ${ }^{7}$

National Health Commission of the People's Republic of China melaporkan bahwa ada 3.387 nakes terinfeksi COVID-19, dengan tingkat kematian sekitar 22 orang $(0,6 \%)$ dan lebih dari 90\% nakes yang terinfeksi berasal dari Provinsi Hubei. ${ }^{8}$ Di Indonesia, jumlah nakes yang terinfeksi COVID-19 terus bertambah. Walaupun belum ada data resmi yang dikeluarkan oleh pemerintah terkait dengan jumlah dokter dan perawat yang terinfeksi COVID-19 dan penyebarannya secara nasional. Tim Gugus Tugas Percepatan Penanganan COVID-19 mencatat jumlah tenaga medis meninggal akibat terinfeksi COVID-19 sebanyak 55 orang per 6 Mei 2020. ${ }^{9}$ Nakes terinfeksi COVID-19 terbanyak berada di wilayah DKI Jakarta, dengan jumlah 174 tenaga medis. ${ }^{10}$

Adapun penulisan ini bertujuan menganalisis kebijakan yang dikeluarkan oleh pemerintah Indonesia, khususnya pemerintah pusat, terkait dengan perlindungan nakes pada saat pandemi COVID-19. Penulisan ini menggunakan studi literatur dengan menelaah regulasi, konferensi pers Gugus Tugas Percepatan Penanganan COVID-19, jurnal ilmiah, 18 artikel media massa nasional dan 2 artikel media massa internasional (elektronik), webinar, dan data terkait nakes yang menangani COVID-19 dengan waktu April-Mei 2020. Analisis data menggunakan segitiga kebijakan Waltz and Gilson.

\section{Masalah Nakes Selama Pandemi COVID-19}

Di Indonesia isu kurangnya Alat Pelindung Diri (APD) merupakan salah satu faktor yang menyebabkan penularan COVID-19 kepada nakes, meskipun saat ini supply APD terus ditingkatkan. Hingga 27 April 2020, Ikatan Dokter Indonesia (IDI) melaporkan bahwa masih banyak nakes di berbagai daerah yang kekurangan APD. ${ }^{11}$ Bahkan di awal pandemi, nakes terpaksa menggunakan jas hujan plastik untuk mengatasi kekurangan APD. ${ }^{12}$ Sampai Mei 2020, APD yang dibutuhkan mencapai 35 juta unit, sedangkan yang tersedia baru 1,2 juta unit pada 11 April 2020. APD yang standar merupakan bagian penting dari prosedur perlindungan nakes. ${ }^{13}$ Terkait hal ini, lima organisasi kesehatan Indonesia dan Amnesty Internasional memberikan surat terbuka ${ }^{14}$ kepada pemerintah guna mendesak agar lebih memperhatikan standar hak asasi manusia dan perlindungan hak-hak nakes dalam strategi pencegahan dan penanganan COVID-19, salah satunya melalui penyediaan APD yang berkualitas dan proses distribusi yang merata.

Untuk mencegah risiko terinfeksi, maka di masa pandemi jumlah permintaan APD sangatlah tinggi, ${ }^{15} \mathrm{WHO}$ dalam pemodelannya memperkirakan permintaan internasional per bulan untuk kebutuhan masker medis sebanyak 89 juta perbulan, sarung tangan 76 juta perbulan, dan kacamata 1,6 juta perbulan. ${ }^{16}$

Di samping rentan terinfeksi COVID-19 karena kurangnya APD, nakes juga mengalami isu psikososial, seperti stigmatisasi dan diskriminasi dari kelompok tertentu di masyarakat, ${ }^{17}$ tidak sedikit nakes yang ditolak atau diminta pindah dari rumah sewanya karena menangani pasien COVID-19.18 Selain itu, jenazah nakes yang akan dikebumikan di pemakaman umum ditolak oleh masyarakat sekitar. ${ }^{19}$ Dukungan sosial sulit pula didapatkan oleh nakes karena padatnya jadwal bekerja dan harus tinggal terpisah dengan keluarga selama menangani pasien COVID-19. ${ }^{17}$ Di Cina dilaporkan bahwa angka kecemasan nakes selama pandemi sebesar $45 \% .{ }^{20}$ Di Indonesia sebanyak 42,2\% nakes menyatakan memerlukan layanan kesehatan jiwa. ${ }^{21}$

Di samping risiko terinfeksi COVID-19 dan isu psikososial, nakes juga mengalami kelelahan fisik karena semakin banyaknya jumlah pasien. Kurangnya jumlah nakes juga menyebabkan mereka harus bekerja double shift atau lebih dari 8 jam. ${ }^{22}$ Permasalahan kurangnya nakes dapat terlihat dari rasio total nakes tahun 2019 di Indonesia yang hanya sebesar 1:213 per 100.000 penduduk, bila melihat rasio dokter, WHO mencatat bahwa Indonesia memiliki rasio 0,4 dokter per 1.000 penduduk, ${ }^{23}$ jika dibandingkan dengan Amerika Serikat, yang memiliki rasio 2,5 dokter per 1.000 penduduk, jumlah dokter di Indonesia juga minim. ${ }^{23}$ Secara nasional, saat ini tenaga medis yang menangani COVID-19 di 34 provinsi per 13 Mei 2020, yaitu 
dokter umum 10.975 orang, dokter spesialis paru 736 orang, dan perawat 128.285 orang.

Gambar 2 menunjukkan di level provinsi di Pulau Jawa, Banten memiliki jumlah dokter yang sangat minim dibandingkan provinsi lain yang terdampak COVID-19 secara masif, dengan jumlah dokter 119 orang dan dokter spesialis 8 orang. Adapun total nakes yang menangani COVID-19 di 702 rumah sakit (RS)rujukan COVID-19, yakni 190.164 orang, ${ }^{24}$ dengan distribusi dokter dan perawat terbanyak di Pulau Jawa.

Adanya masalah yang dihadapi nakes di Indonesia dalam menghadapi COVID-19, seperti

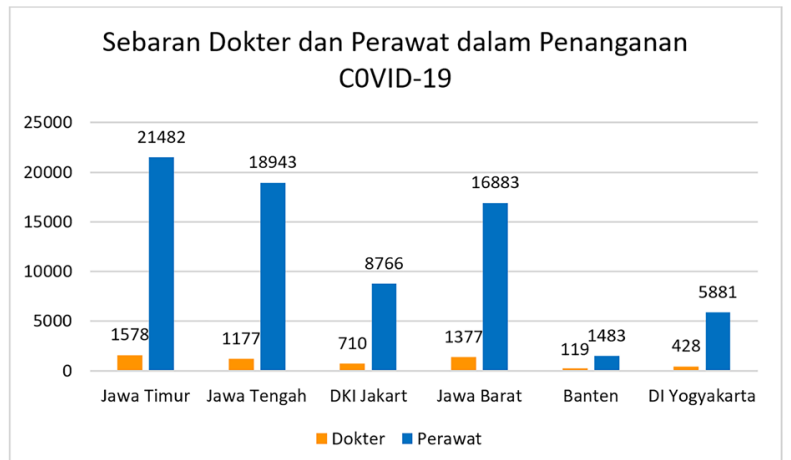

Gambar 2. Grafik Sebaran Dokter dan Perawat yang Menangani COVID-19

Sumber : diolah dari Badan Pengembangan dan Pemberdayaan Sumber Daya Manusia Kesehatan (BPPSDMK) Kemenkes RI

kurangnya APD, isu psikososial, dan kelelahan fisik menunjukkan, terdapat masalah pada sistem kesehatan, terutama terkait dengan perlindungan terhadap nakes di Indonesia, yang perlu diperbaiki mulai dari tingkat pusat hingga daerah.

\section{Kebijakan Pemerintah Indonesia Terkait Perlindungan terhadap Nakes}

Kebijakan yang diambil pemerintah dalam penanggulangan COVID-19 sebagai berikut:

Tabel 1 menunjukkan, ada berbagai kebijakan yang diputuskan pemerintah pusat terkait dengan perlindungan nakes, seperti relaksasi kebijakan terkait izin edar alat medis selama pandemi, pemberian insentif dan santunan kematian, telemedicine bagi dokter untuk memberikan konsultasi, penerbitan buku pedoman oleh Kemenkes mengenai standardisasi ${ }^{25}$ APD yang direkomendasikan WHO dan CDC, serta penyediaan fasilitas penginapan dan transportasi bagi nakes dan relawan penanggulangan COVID-19 melalui Kementerian Pariwisata dan Ekonomi Kreatif (Kemenparekraf). Untuk menjamin pasokan APD dan menekan jumlah pasien COVID-19, pemerintah mewajibkan masyarakat memakai masker kain, bila keluar rumah. Selain itu, pemerintah juga memberikan layanan sehat jiwa hotline 119 ext 8, dan melalui Kementerian Kesehatan (kemenkes) buku pedoman dukungan kesehatan jiwa dan psikosial, Kementerian Sosial (Kemensos) membentuk tim pendamping tenaga medis serta meluncurkan layanan dukungan psikososial melalui hotline dan konseling online yang dapat digunakan oleh nakes.

\section{Analisis Kebijakan dengan Segitiga Kebijakan Waltz and Gilson}

Buse, Mays, \& Walt (2012) ${ }^{26}$ mendefinisikan kebijakan sebagai "keputusan yang diambil oleh pihak-pihak yang bertanggung jawab atas area kebijakan tertentu", Kebijakan Publik merujuk pada kebijakan-kebijakan yang dibuat oleh negara atau pemerintah". Dalam segitiga kebijakan ada 4 komponen yang dianalisis yaitu Konten, Konteks, Proses dan Aktor yang terlibat dalam kebijakan tersebut. Berikut dalam Gambar 3 adalah Segitiga Analisis Kebijakan:

Analisis Konten dalam Implementasi Kebijakan Perlindungan Nakes dalam Menghadapi

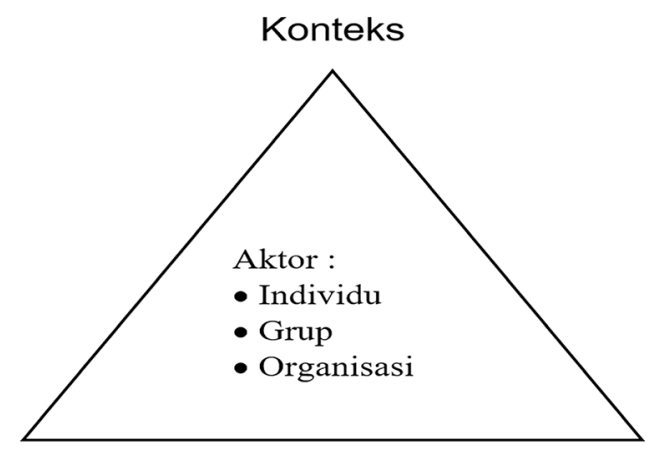

\section{Konten/Isi \\ Gambar 3. Segitiga Analisis Kebijakan}

\section{COVID-19 di Indonesia}

Perlindungan nakes telah menjadi program prioritas pemerintah Indonesia saat ini. Berbagai kebijakan cepat diambil agar nakes merasa aman dan terlindungi dalam melayani pasien. ${ }^{27}$ Hasil telaah literatur, regulasi, media, berikut kebijakankebijakan yang diambil pemerintah adalah sebagai berikut. 
Tabel 1. Berbagai Kebijakan Pemerintah Indonesia terkait dengan Perlindungan terhadap Nakes yang Terlibat dalam Penanganan COVID-19

\begin{tabular}{|c|c|c|c|}
\hline No & $\begin{array}{c}\text { Kebijakan } \\
\text { Terkait }\end{array}$ & Jenis Peraturan/ Kebijakan & Kesimpulan Peraturan/ Kebijakan \\
\hline \multirow[t]{3}{*}{1} & \multirow[t]{2}{*}{ APD } & $\begin{array}{l}\text { Relaksasi Kebijakan: } \\
\text { Peraturan Menkes RI No 7/2020, } \\
\text { dan Keputusan Menkes RI No } \\
218 / 2020\end{array}$ & $\begin{array}{l}\text { Pemasukan alat kesehatan untuk penanggulangan COVID-19 } \\
\text { tidak memerlukan izin edar dan SAS dari Kemenkes }\end{array}$ \\
\hline & & Peraturan Mendag RI No 23/2020 & Larangan ekspor sementara perlengkapan APD \\
\hline & \multirow{6}{*}{$\begin{array}{l}\text { Insentif } \\
\text { Nakes }\end{array}$} & $\begin{array}{l}\text { Keputusan Menkes RI No } \\
\text { HK.01.07/MENKES/278/2020 }\end{array}$ & $\begin{array}{l}\text { Nakes yang menangani COVID-19 diberikan insentif dan } \\
\text { santunan kematian mulai bulan Maret-Mei } 2020 \text { dan dapat } \\
\text { diperpanjang sesuai dengan ketentuan peraturan perundang- } \\
\text { undangan }\end{array}$ \\
\hline \multirow[t]{5}{*}{2} & & & $\begin{array}{l}\text { Tenaga medis dan dokter yang terlibat langsung dalam } \\
\text { penanganan COVID-19 akan mendapatkan insentif nakes. } \\
\text { Besaran insentif per bulan: }\end{array}$ \\
\hline & & Surat Menkeu RI No. S-239/ & - Dokter Spesialis maksimal Rp15.000.000,00 \\
\hline & & MK.02/2020 & - Dokter Umum dan Dokter Gigi maksimal Rp10.000.000,00 \\
\hline & & & - Bidan dan Perawat maksimal Rp 7.500.000,00 \\
\hline & & & - Nakes Lainnya maksimal Rp 5.000.000,00 \\
\hline \multirow{2}{*}{3} & \multirow{2}{*}{$\begin{array}{l}\text { Fasilitas } \\
\text { dan } \\
\text { Praktik } \\
\text { Kesehatan }\end{array}$} & $\begin{array}{l}\text { Surat Edaran Menkes RI No } \\
\text { HK.02.01/MENKES/3030/2020 }\end{array}$ & $\begin{array}{l}\text { Untuk mencegah penyebaran COVID-19, dokter yang } \\
\text { meliputi dokter, dokter gigi, dokter spesialis, dokter gigi } \\
\text { spesialis, dan dokter subspesialis dapat memanfaatkan } \\
\text { teknologi informasi dan komunikasi berupa telemedicine } \\
\text { dalam pemberian pelayanan kesehatannya. }\end{array}$ \\
\hline & & $\begin{array}{l}\text { Penyediaan sarana transportasi dan } \\
\text { penginapan (diumumkan melalui } \\
\text { Siaran Pers Kemenparekraf/Badan } \\
\text { Pariwisata dan Ekonomi Kreatif } \\
\text { tanggal } 28 \text { Maret } 2020\end{array}$ & $\begin{array}{l}\text { Kemenparekraf memfasilitasi pemanfaatan hotel dan } \\
\text { transportasi untuk tenaga medis dan gugus tugas }\end{array}$ \\
\hline \multirow[b]{2}{*}{4} & \multirow[b]{2}{*}{ Pedoman } & $\begin{array}{l}\text { Buku Pedoman yang diterbitkan } \\
\text { oleh Ditjen Farmalkes Kemenkes RI }\end{array}$ & Standar APD dalam Manajemen Penanganan COVID-19 \\
\hline & & $\begin{array}{l}\text { Kewajiban memakai masker } \\
\text { (diumumkan melalui Konferensi } \\
\text { Pers Juru bicara Pemerintah untuk } \\
\text { Penanganan COVID-19) }\end{array}$ & $\begin{array}{l}\text { Masyarakat diwajibkan memakai masker ketika di luar } \\
\text { rumah, khususnya masker kain }\end{array}$ \\
\hline \multirow{3}{*}{5} & \multirow{3}{*}{ Layanan } & $\begin{array}{l}\text { Buku Pedoman yang diterbitkan } \\
\text { Ditjen Pencegahan dan Pengendalian } \\
\text { Penyakit Kemenkes RI }\end{array}$ & $\begin{array}{l}\text { Pedoman Dukungan Kesehatan Jiwa dan Psikososial pada } \\
\text { Pandemi COVID-19 }\end{array}$ \\
\hline & & $\begin{array}{l}\text { Program Layanan Psikososial yang } \\
\text { diluncurkan oleh Kementerian Sosial } \\
\text { (Kemensos) }\end{array}$ & $\begin{array}{l}\text { Kemensos membentuk tim relawan sosial pendamping tenaga } \\
\text { medis dan membuka konseling online } 24 \text { jam }\end{array}$ \\
\hline & & $\begin{array}{l}\text { Layanan konseling Sehat Jiwa } \\
\text { (SEJIWA) yang diluncurkan oleh } \\
\text { Kantor Staf Presiden }\end{array}$ & $\begin{array}{l}\text { Layanan konseling SEJIWA dapat diakses melalui hotline } \\
119 \text { ext } 8 \text {, disambungkan ke relawan Himpunan Psikologi } \\
\text { Indonesia (HIMPSI) }\end{array}$ \\
\hline
\end{tabular}

Sumber : Media Nasional Indonesia dan web resmi (https://covid19.go.id/ https://www.kemkes.go.id/) 


\section{a) APD}

Kelangkaan APD di hampir semua RS, telah menjadi isu global, tidak hanya di Indonesia namun di dunia. Pada awal kemunculan pandemi COVID-19 terjadi kelangkaan masker medis akibat panicbuying, masyarakat menimbun masker sehingga harga masker medis melambung tinggi. Imbauan pemerintah untuk wajib menggunakan masker kain selain untuk perlindungan masyarakat juga untuk menjamin pasokan masker medis, agar masker medis diprioritaskan untuk nakes yang memiliki risiko tinggi terinfeksi. Kenyataan di lapangan masih ada daerah yang masih membutuhkan APD seperti dirilis media $\mathrm{CNN}^{28}$ "Provinsi NTT, misalnya, membutuhkan 17 juta liter disinfektan berisi chlorine, Sumsel butuh 250 juta masker biasa dan Provinsi DI Yogyakarta masih kekurangan 3,2 juta unit APD”. Untuk memenuhi demand, Kemenperin menargetkan produksi APD 3 juta unit perminggu, dengan target produksi perbulan 17 juta APD. ${ }^{29}$

Dalam diskusi webinar pada tanggal 7 April 2020 yang diselenggarakan PKMK UGM dengan pembicara Direktur Jenderal Farmalkes Kemenkes RI, terungkap menyatakan ada dua regulasi yang direlaksasi ${ }^{30,31}$ di antaranya Permenkes No 7/2020 tentang perubahan atas Permenkes No 51/2014 tentang pemasukan alat kesehatan (alkes) melalui mekanisme jalur khusus special access scheme, dan Keputusan Menkes RI No 218/2020 tentang alkes, alkes diagnostik in vitro, dan perbekalan kesehatan rumah tangga yang dikecualikan dari perizinan tata niaga dalam rangka penanggulangan COVID-19.

Permenkes No 7/2020 pasal 6A ayat 1 berbunyi: "alat kesehatan yang dimasukkan melalui SAS untuk keperluan penanggulangan wabah dan/ atau kedaruratan kesehatan masyarakat dapat beredar tanpa memiliki izin sebagaimana dimaksud dalam pasal 5 dan pasal 6". Dengan adanya relaksasi peraturan ini semua alkes impor dalam masa wabah dan kedaruratan kesehatan masyarakat tidak memerlukan izin edar, ${ }^{32}$ termasuk diagnostic test, rapid test, cukup hanya rekomendasi dari ketua Gugus Tugas Percepatan Penanganan COVID-19 baik untuk donasi maupun komersial, ${ }^{33}$ sehingga banyak pelaku usaha melakukan diversifikasi. Tercatat produksi masker naik $77 \%$, produksi hand sanitizer naik $186 \%$, dan yang paling signifikan kenaikan produksi APD 567\%.
Untuk menjamin supply-demand APD, Kementerian Perdagangan (Kemendag) mendorong kapasitas produksi APD dengan melibatkan industri tekstil, per 28 April 2020 Indonesia telah memiliki 28 produsen dan telah menghitung jumlah kebutuhan nasional APD 6-8 bulan ke depan. Kemendag juga mengeluarkan larangan ekspor sementara produk antiseptik, bahan baku masker, APD, dan masker yang ditetapkan melalui Peraturan Mendag RI No 23 Tahun $2020 .{ }^{29}$

Banyaknya donasi APD dari masyarakat menjadi perhatian khusus, karena APD yang diberikan juga harus berkualitas sehingga tidak meningkatkan risiko transmisi virus kepada petugas kesehatan. Masyarakat tidak mengetahui standar APD yang digunakan tenaga medis sehingga bantuan bisa berubah menjadi bencana bagi nakes. Ada panduan sementara ${ }^{6}$ yang ditetapkan oleh WHO pada tanggal 6 April 2020 untuk penggunaan rasional APD untuk COVID-19 dan pertimbangan jika ketersediaan sangat terbatas. Ini bisa menjadi rujukan bagi RS dalam menilai APD yang diterima ataupun dibeli, diperlukan pengawasan dalam menyeleksi APD yang diterima pihak RS. Mengenai standar APD, Ditjen Farmalkes Kemenkes RI juga telah menerbitkan buku standar $\mathrm{APD}^{25}$ dalam manajemen penanganan COVID-19, di mana persyaratan material bahan APD yang standar diatur di dalamnya.

\section{b) Insentif}

Salah satu bentuk dukungan perlindungan pemerintah terhadap nakes adalah memberikan insentif kepada nakes yang terlibat langsung dalam penanganan COVID-19 terhitung bulan Maret-Mei 2020. Hal ini sesuai dengan surat Menkeu Nomor S-239/MK.02/2020 dengan besaran berbeda-beda tergantung assessment risiko paparan COVID-19. Assessment dilakukan oleh RS sesuai petunjuk teknis dari Kemenkes. ${ }^{34}$ Pemberian insentif bagi nakes juga berdasarkan Keputusan Menkes RI No HK.01.07/MENKES/278/2020. ${ }^{35}$ Besaran insentif yang diberikan oleh pemerintah Indonesia dengan jumlah kasus yang ditangani saat dan rasio nakes dapat dikatakan rendah, jika dibandingkan dengan kebijakan negara Taiwan, dengan jumlah kasus 440 kasus, insentif rata-rata nakes mempeoleh \$335 (Rp 4.998.200) per shift. ${ }^{36}$ Namun besaran insentif 
di Indonesia lebih baik dari Malaysia yang ratarata mendapatkan RM 600 (Rp.2.064.642) sampai wabah berakhir. ${ }^{37}$

Dalam dokumen World Bank ${ }^{38}$ yang memetakan kebijakan-kebijakan perlindungan sosial terkait COVID-19 di 171 negara, sebagian negara mengambil kebijakan paid sick support. Misalnya pemerintah Malaysia menetapkan cuti sakit (paid sick leave) kepada tenaga medis selama periode isolasi tanpa ada pemotongan insentif/gaji. Hal ini perlu menjadi pertimbangan untuk diadopsi dalam membuat rencana ke depan untuk perlindungan nakes di Indonesia khususnya pada saat pandemi.

\section{c) Telemedicine}

Langkah kebijakan pemerintah berikutnya melalui Kemenkes dengan diterbitkannya Surat Edaran Menkes RI No HK.02.01/ MENKES/303/2020 ${ }^{39}$ tentang Penyelenggaraan Pelayanan Kesehatan melalui pemanfaatan teknologi informasi dan komunikasi dalam rangka pencegahan penyebaran COVID-19. Pelayanan telemedicine dilakukan oleh dokter dengan menggunakan teknologi informasi untuk mendiagnosis, mengobati, mencegah dan/atau mengevaluasi kondisi kesehatan pasien. Hal ini sesuai dengan ${ }^{40}$ Permenkes No 20 Tahun 2019 tentang Penyelenggaraan Pelayanan Telemedicine antar-fasyankes (fasilitas pelayanan kesehatan), disebutkan aplikasi adalah salah satu syarat dalam memberikan pelayanan telemedicine dan pada Pasal 12 ayat 2 "aplikasi sebagaimana dimaksud pada ayat (1) disediakan Kemenkes".

Indonesia Telemedicine Association (Atensi) memiliki 12 layanan perusahan kesehatan digital. Penggunaan telemedicine/telehealth telah banyak digunakan di negara-negara maju untuk triase pasien dan meminimalkan pasien kontak dengan petugas kesehatan. ${ }^{41}$ Di Amerika Serikat lebih dari 50 sistem kesehatan telah menerapkan program ini, terutama pada masa pandemi COVID-19, pasien dapat menjadwalkan video kunjungannya dan melihat kondisi pasien di rumah. Program ini dinilai dapat meminimalkan risiko petugas kesehatan untuk tertular infeksi COVID-19 dari pasien, ditambah banyak pasien yang tidak jujur dengan kondisinya.

d) Layanan psikososial terhadap nakes

Saat ini layanan psikososial nasional adalah hotline 119 ext 8 dan buku pedoman kesehatan jiwa dan psikososial pada pandemi COVID-19 yang masih bersifat umum. Nakes berisiko tinggi terinfeksi COVID-19 dan rentan mengalami tekanan psikososial, sehingga diperlukan pedoman khusus dukungan kesehatan jiwa dan psikososial bagi nakes. Berdasarkan hasil survei RS Dr Cipto Mangunkusumo (RSCM), 42,2 \% nakes di RSCM tersebut menyatakan memerlukan layanan kesehatan jiwa, berupa konseling, psikoterapi baik online maupun tatap muka. Hasil survei mengungkapkan kekhawatiran-kekhawatiran responden akan kondisi kesehatannya, kemungkinan menularkan ke anggota keluarganya, biaya hidup dan pengobatan, serta takut dikucilkan dan mendapat diskriminasi. Sebanyak 50-70\% klien melakukan konseling sesuai jadwal dan mayoritas bertugas di ruang perawatan dan IGD. $^{21}$

Kemensos membentuk tim relawan sosial pendamping tenaga medis dan diterjunkan langsung untuk mendampingi para tenaga medis. Pendampingan menggunakan metode berbasis informasi (IT) dan daring. Fokus utama adalah penguatan sistem perawatan kesehatan selama pandemi, yang penting untuk mengurangi kecemasan nakes pada saat bekerja pada masa pandemi. ${ }^{20}$ Dukungan sosial, menurut literatur, dapat meningkatkan self-efficacy dan mengurangi tingkat cemas dan stres.

\section{Analisis Konteks dalam Implementasi Kebijakan Perlindungan terhadap Nakes dalam Menghadapi COVID-19 di Indonesia}

Ditinjau dari segi konteks, kebijakankebijakan yang diambil dalam memberikan perlindungan nakes bersifat situasional. Kebijakan ini dikenal sebagai "focusing event" hanya bersifat satu kejadian (perang, wabah) ${ }^{26}$, yang memerlukan perbaikan update kebijakan yang sudah ada dan disesuaikan dengankemajuan dunia. Teknologimedis seharusnya banyak berperan dalam penanganan wabah seperti COVID-19 agar mengurangi risiko nakes terpapar. Kebijakan-kebijakan pemerintah Indonesia harus dilihat sebagai satu kesatuan tidak terpisah-pisah, dan dipimpin oleh satu komando. Dalam konteks bencana, sangat diperlukan ${ }^{42}$ kerja sama multisektoral, pendekatan yang kompherensif, edukasi kesehatan masyarakat, membangun sistem kesehatan kebencanaan yang kuat khususnya 
bencana non-alam, dan memperkuat komunikasi publik.

\section{Analisis Proses dalam Implementasi Kebijakan Perlindungan terhadap Nakes dalam Menghadapi COVID-19 di Indonesia}

Kebijakan perlindungan terhadap nakes perlu dipantau untuk memastikan proses pelaksanaannya kebijakan perlindungan tenaga kesehatan berjalan dengan semestinya dan dapat menyelesaikan dampak yang ada di pelayanan kesehatan. Distribusi APD keseluruh ke 34 provinsi memang tidak mudah mengingat letak geografis Indonesia yang cukup luas, diperlukan kerja sama antara pemerintah daerah provinsi, kabupaten, kota, dinas kesehatan, dan industri sehingga penyampainnya cepat dan tepat sasaran. Pelaksanaan kebijakan ini dilakukan di bawah komando Gugus Tugas Percepatan Penanganan COVID-19 dan dengan mengerahkan pesawat TNI Angkatan Udara dalam pendistribusiannya. Kondisi saat ini per 11 Mei 2020, Kemenkes telah mendistribusikan APD sebanyak 1.793.095 set, Rapid Test 691.500 pcs dan masker bedah sebanyak 13.212 .020 pcs ke 34 provinsi, dan pendistribusian di daerah dikoordinasikan oleh dinas kesehatan provinsi. ${ }^{43}$ Jumlah ini sebaiknya terus bertambah mengingat kebutuhan APD sampai Juni 2020 sebanyak 5-8 juta.

Berkaitan dengan ketersediaan bahan baku, Presiden menginstruksikan agar Bea Cukai, Kemendag merelaksasi kebijakannya terkait izin impor bahan baku. Keterlibatan seluruh industri usaha mikro, kecil, menengah (UMKM) di Indonesia juga menjadi salah satu kebijakan pemerintah untuk mempercepat penyediaan APD. ${ }^{44}$ SOP pemakaian APD yang standar juga sudah dikeluarkan oleh Kemenkes untuk melindungi nakes. Untuk memastikan penyaluran APD tepat sasaran dan memudahkan tracking, gugus tugas menerbitkan Prosedur Tetap dan Panduan Distribusi Alat Material Kesehatan.

Pola kebijakan insentif kini bersifat "Direct Incentives", di mana dibagi menjadi dua, yaitu financial incentives and non-financial incentives, seperti gambar di bawah ini :

Gambar 4 menunjukkan dalam penelitian Dambisya YM Tahun 2007, ${ }^{45}$ keberhasilan penerapan insentif non-financial terhadap retensi dan motivasi petugas kesehatan dalam memberikan pelayanan berkualitas. Insentif non-financial termasuk hari libur, jam kerja fleksibel, peluang pelatihan, cuti studi, konseling kesehatan kerja, dan fasilitas rekreasi. Pada konteks kebijakan umum insentif langsung dan tidak langsung memengaruhi sistem kesehatan, desain sistem kesehatan, kebijakan dan konteksnya.

Kebijakan saat ini untuk melindungi nakes dengan memberikan reward berupa insentive financial. Kebijakan terkait dengan jaminan perlindungan hukum, life insurance sangat diperlukan. Ini sesuai dengan UU No 36 Tahun 2014 Pasal 57 huruf a " tenaga kesehatan dalam menjalankan praktik berhak memperoleh pelindungan hukum sepanjang melaksanakan tugas sesuai dengan standar profesi, standar pelayanan profesi, dan standar prosedur operasional. Huruf d "memperoleh perlindungan atas keselamatan dan kesehatan kerja, perlakuan yang sesuai dengan harkat dan martabat manusia, moral, kesusilaan, serta nilai-nilai agama. ${ }^{45}$ Proses pelaksanaan kebijakan pemberian insentif harus dipantau dan dievaluasi mulai dari tingkat provinsi hingga kabupaten/kota, sehingga tepat sasaran dan besaran yang diberikan juga sesuai dengan yang ditetapkan oleh pemerintah. Strategi ini diperlukan agar petugas kesehatan lebih termotivasi dalam memberikan pelayanan, reward yang diberikan disesuaikan dengan beban kerja, khususnya dalam penanganan COVID-19, insentif berupa dukungan psikologis sangatlah penting bagi petugas kesehatan agar terhindar dari stigma dan diskriminasi.

Pada proses kebijakan telemedicine, Indonesia memiliki 12 layanan perusahaan kesehatan digital, ada 300.000 masyarakat menggunakan layanan telemedicine. ${ }^{46} \mathrm{Hal}$ ini merupakan langkah yang baik untuk meminimalkan risiko penularan COVID-19. Penggunaan telemedicine dengan menggunakan telekonsultasi/pemeriksaan kesehatan virtual melalui real time video yang diinterpretasikan oleh dokter sudah ada sejak 2015. Kemenkes saat ini telah bekerja sama dengan perusahaan start-up Gojek, Grab, Halodoc, dan Good Doctor. Namun, masih ada prokontra ${ }^{47}$ terhadap telemedicine, seperti diagnosis yang diberikan hanya bersifat sementara karena dokter tidak memeriksa fisik, telemedicine tidak bisa menggantikan kunjungan pasien ke 


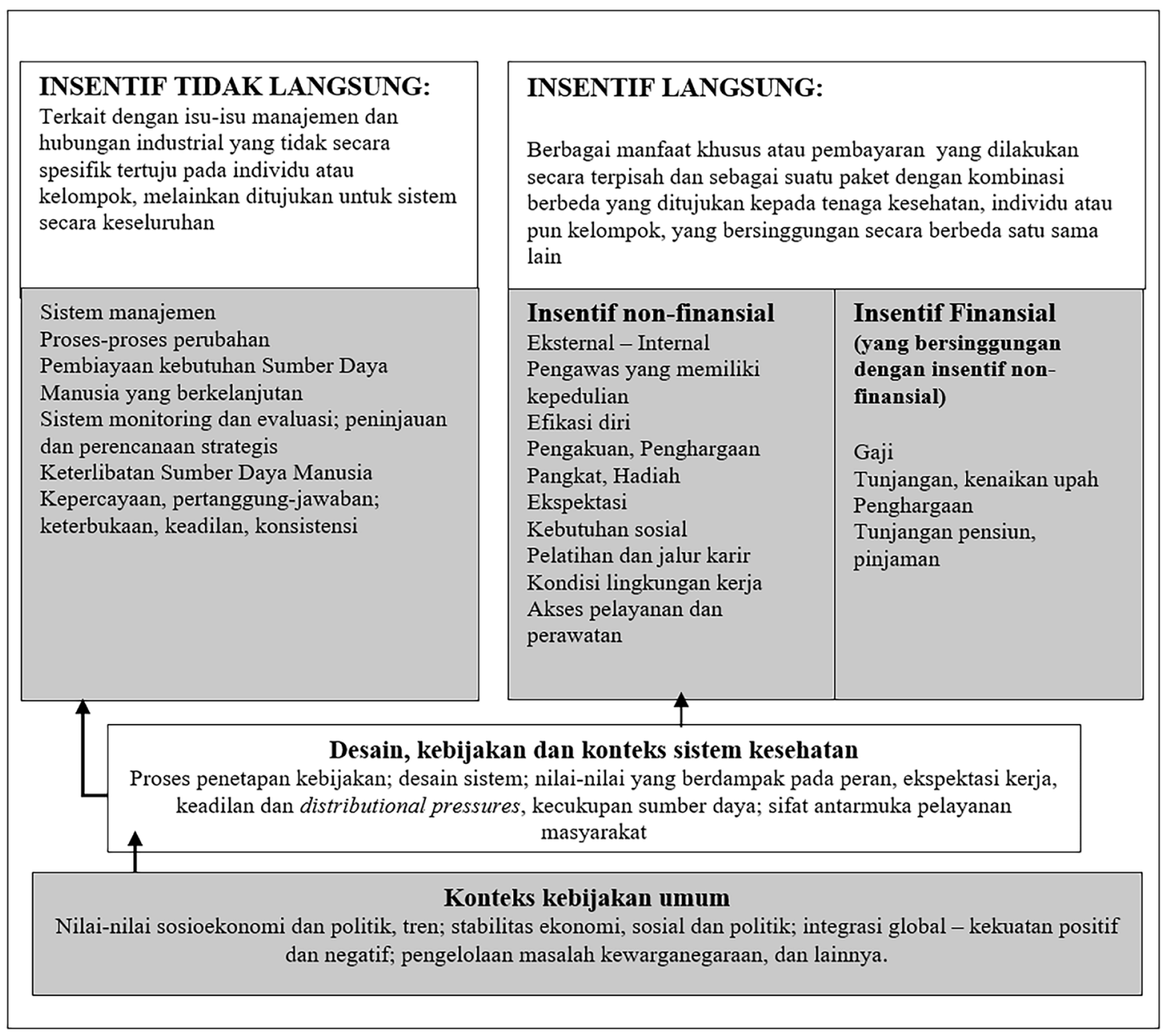

Sumber : Diolah dari Luoma (2006) dan Arah, Westurt, Hurst and Klazinga (2006) dalam Dambisya (2007)

\section{Gambar 4. Kerangka Konsep Insentif Non-finansial untuk Retensi Nakes}

pelayanan kesehatan, dan telemedicine hanya pendamping dalam perawatan.

Keamanan data pasien menjadi isu penting dalam menerapkan telemedicine. Menurut CEO Healthcare Information and Management Systems Society (HIMSS), ${ }^{48}$ tantangan dalam menerapkan telemedicine adalah aspek nonteknis seperti perubahan kultur kerja, mindset, struktur organisasi, dan tata kelola organisasi. Untuk keberhasilan pelaksanaan program ini, daerah juga ikut dalam penerapannya, dan terbuka terhadap perubahan teknologi di bidang kesehatan. Kondisi saat ini beberapa RS telah menggunakan layanan telemedicine, seperti teleconsultation, homecare, pengiriman obat, ${ }^{49}$ dan aplikasi untuk pelayanan rujukan pasien..$^{50}$

Pelaksanaan layanan kesehatan jiwa dan psikososial harus disertai dengan upaya penyebaran informasi dan sosialisasi secara nasional yang dapat ditingkatkan melalui kerja sama antara pemerintah dengan fasyankes yang menangani COVID-19 dan organisasi profesi terkait. Di samping adanya layanan online yang saat ini beberapa RS, seperti RSCM, memberikan layanan kesehatan nakes.

\section{Aktor yang Terlibat dalam Implementasi Kebijakan Perlindungan terhadap Nakes dalam Menghadapi COVID-19 di Indonesia}

Dalam penanganan pandemi global diperlukan kolaborasi multisektor, multimitra, institusi pemerintah dan swasta, akademisi, organisasi, individu, serta komunitas. Dalam pengambilan kebijakan berikut para pelaku penyusun kebijakan baik dari pemerintah maupun nonpemerintah serta pengkategoriannya:

a) Pemerintah pusat dan daerah (Presiden RI 
Menteri Kesehatan, Menteri Keuangan, Menteri Sosial, Menteri Pariwisata dan Ekonomi Kreatif, Menteri Perdagangan, Gubernur, Walikota, Bupati, Camat, Lurah, Kepala Desa), berperan mengambil keputusan cepat dan tepat berbasis data, serta menjamin kesejahteraan masyarakat khususnya pada keadaan pandemi COVID-19.

b) Organisasi nasional (Gugus Tugas Percepatan Penanganan COVID-19), sebagai media informasi resmi pemerintah kepada masyarakat dalam memberikan laporan perkembangan penyakit dalam mencegah, mendeteksi dan merespon COVID-19

c) Organisasi profesi kesehatan dan kedokteran, PERSI, dan sebagainya, berperan memberikan masukan kepada pemerintah mengenai langkahlangkah yang diambil berdasarkan keilmuan, serta menjadi wadah nakes.

d) Organisasi internasional (WHO, World Bank, Global Health Workforce Alliance), berperan sebagai media informasi ilmiah yang memberikan panduan-panduan ke seluruh negara serta memberikan masukan dalam merespon pandemi COVID-19.

e) Industri (GAKESLAB, Alkes) berperan memberi masukan kepada pemerintah untuk memenuhi pasokan alkes khususnya dalam merespon pandemi COVID-19.

f) Pemilik media massa nasional (media sosial, media cetak, media elektronik, televisi), berperan sebagai media komunikasi yang akurat berbasis data, mengawasi pelaksanaan kebijakan pemerintah di lapangan.

g) Perusahaan start-up, berperan dalam menyokong pemerintah untuk mempermudah memenuhi kebutuhan masyarakat baik dari segi sosial, pendididikan, maupun ekonomi.

h) Tokoh agama, tokoh masyarakat, relawan maupun influencer berperan dalam membantu mengedukasi masyarakat dan memberikan masukan pada pemerintah mengenai kondisi di lapangan/masyarakat saat pandemi.

Kelemahan dalam tulisan ini yakni sulitnya mendapatkan data resmi jumlah nakes yang meninggal. Pemerintah perlu menghimpun data yang aksesibel, terkini, dan akurat terkait dengan jumlah nakes yang terinfeksi dan yang meninggal.

\section{Kesimpulan}

Pemerintah pusat telah menetapkan dan melaksanakan kebijakan-kebijakan terkait dengan perlindungan nakes di Kementerian dan Lembaga, di antaranya relaksasi kebijakan izin produksi APD, melibatkan industri usaha, mikro, kecil, menengah (UMKM). Pengawasan kualitas donasi APD masih berada di level RS. Kebijakan insentif saat ini bersifat finansial selama tiga bulan dengan tingkat penilaian risiko yang berbeda-beda. Meskipun Kemensos membentuk tim pendamping khusus untuk tenaga medis, layanan psikososial berupa konseling online dan buku pedoman bersifat umum. Penggunaan telemedicine dalam metode pemberian pelayanan kesehatan menuai pro dan kontra khususnya dalam penegakan diagnosis penyakit.

\section{Saran}

Pemerintah perlu melakukan monitoring sampai ke daerah untuk memastikan ketersediaan APD yang berkualitas dan sesuai standar medis. Insentif finansial bagi nakes tidak hanya tiga bulan, namun hingga wabah berakhir. Insentif bersifat nonfinansial, seperti dukungan psikososial, diperlukan dengan membuat pedoman khusus kesehatan jiwa bagi nakes yang menangani pandemi. Upaya penyebaran informasi dan sosialisasi layanan kesehatan jiwa secara online skala nasional diperlukan. Kebijakan paid sick leave support juga perlu diterapkan bagi nakes yang jatuh sakit karena menangani pandemi COVID-19. Paid sick leave dapat diberikan kepada nakes sesuai dengan periode waktu isolasi atau perawatan.

Pelayanan kesehatan mempertimbangkan jumlah jam kerja nakes, khususnya yang bekerja di unit-unit kritis dan kegawatdaruratan, serta memantau melalui komite Pencegahan dan Pengendalian Infeksi (PPI) manajemen patient safety. Teknologi medis harus terus dikembangkan dengan kolaborasi multisektor dan perguruan tinggi untuk menyediakan layanan kesehatan berbasis teknologi.

Pemerintah menyediakan pendidikan berkelanjutan dan pelatihan-pelatihan terkait dengan protokol pencegahan penularan COVID-19 guna mempersiapkan nakes menghadapi pandemi saat ini dan di masa yang akan datang. Pemerintah 
daerah harus mengikuti arah kebijakan pemerintah pusat dan memprioritaskan kesejahteraan nakes dalam visi dan misi kebijakannya seperti pemberian insentif finansial dan nonfinansial. Pemerintah daerah perlu memperhatikan nakes yang bekerja di RS nonrujukan COVID-19 dan poliklinik swasta, yang berisiko terinfeksi COVID-19 namun saat ini belum ter-cover dalam kebijakan pemerintah pusat.

Mendorong peran aktif masyarakat juga diperlukan, terutama dalam membudayakan pemakaian masker di ruang publik dan Perilaku Hidup Bersih dan Sehat (PHBS), bukan hanya pada saat pandemi, untuk menurunkan risiko penularan penyakit di masa akan datang.

\section{Kontribusi Penulis}

CGM, SMN, dan MR melakukan proses pengumpulan data, pembahasan, analisis kebijakan. SMN dan MR menyiapkan referensi dan editing. Seluruh penulis membaca dan menyetujui artikel final.

\section{Ucapan Terima Kasih}

Penulis mengucapkan terima kasih kepada Kepala Puslitbang Sumber Daya dan Pelayanan Kesehatan Badan Litbangkes Kementerian Kesehatan RI dan semua pihak yang terlibat dalam penulisan artikel ini.

\section{Daftar Rujukan}

1. Indonesia, Badan Nasional Penanggulangan Bencana. Presiden Tetapkan COVID-19 Sebagai Bencana Nasional [Internet]. 2020. [diakses 19 April 2020]. Tersedia pada: https:// bnpb.go.id/berita/presiden-tetapkan-covid19sebagai-bencana-nasional

2. Indonesia, Gugus Tugas Percepatan Penanganan Covid-19. Infografis COVID-19 (13 Mei 2020) [Internet]. 2020 [diakses 13 Mei 2020] Tersedia pada: https://covid19.go.id/p/berita/infografiscovid-19-13-mei-2020

3. Indonesia, Kementerian Kesehatan, Global Health Workforce Alliance G. Rencana Pengembangan Tenaga Kesehatan Tahun 2011-2025 [Internet]. 2020 [diunduh 17 April 2020].Tersedia pada: https://www.who.int/workforcealliance/countries/inidonesia_hrhplan_2011_2025. pdf
4. Peeri NC, Shrestha N, Rahman MS, Zaki R, Tan $\mathrm{Z}$, Bibi S, et al. The SARS, MERS and novel coronavirus (COVID-19) epidemics, the newest and biggest global health threats: what lessons have we learned? Int J Epidemiol. 2020;49(3): 717-726. doi: 10.1093/ije/dyaa033

5. Chang D, Xu H, Rebaza A, Sharma L, Cruz CSD. Protecting health-care workers from subclinical coronavirus infection. Lancet Respir Med. 2020;8(3):e13.doi:10.1016/S22132600(20)30066-7

6. World Health Organization (WHO). Panduan Sementara Penggunaan Rasional Alat Perlindungan Diri untuk Penyakit Coronavirus (COVID-19) dan Pertimbangan Jika Ketersediaan Sangat Terbatas. WHO: WHO/2019-nCov/IPC_PPE_use/2020.2

7. The Jakarta Post. Over 22,000 healthcare workers infected by COVID-19: WHO [Internet]. 2020. [diakses 28 April 2020].Tersedia pada: https:// www.thejakartapost.com/life/2020/04/12/over22000-healthcare-workers-infected-by-covid19-who.html

8. Wang J, Zhou M, Liu F. Reasons for healthcare workers becoming infected with novel coronavirus disease 2019 (COVID-19) in China. J Hosp Infect. 2020;105(1):100-101. doi:10.1016/j.jhin.2020.03.002

9. Kompas.com. Gugus Tugas: 38 Dokter dan 17 Perawat Meninggal Selama Pandemi Corona [Internet]. 2020. [diakses 13 Mei 2020].Tersedia pada: https://megapolitan.kompas.com/read/ 2020/04/12/17481011/update-12-april-174tenaga-medis-jakarta-positif-covid-19

10. Kompas.com. UPDATE 12 April: 174 Tenaga Medis Jakarta Positif Covid-19 [Internet]. 2020. [diakses 13 Mei 2020]. Tersedia pada: https://megapolitan.kompas.com/ $\mathrm{read} / 2020 / 04 / 12 / 17481011 /$ update-12-april174-tenaga-medis- jakarta-positif-covid-19

11. BBC News Indonesia. Virus corona: Mengapa tenaga kesehatan terus tertular Covid-19 di tengah komitmen pemerintah menyalurkan APD? [Internet]. 2020. [diakses 13 Mei 2020]. Tersedia pada: https://www.bbc.com/indonesia/ indonesia-52434794

12. TribunManado.co.id. Tenaga Medis \& Dokter di Indonesia Pakai Jas Hujan Tangani Pasien 
Covid-19 Disorot Media Asing [Internet]. 2020. [diakses 13 Mei 2020]. Tersedia pada: https:// manado.tribunnews.com/2020/04/17/tenagamedis-dokter-di-indonesia-pakai-jas-hujantangani-pasien-covid-19-disorot-media-asing

13. Indonesia, Perhimpunan Rumah Sakit Seluruh Indonesia (PERSI). Cegah Tenaga Kesehatan Tertular, Kemenkes Ingatkan Semua APD Harus Lolos Uji Lab Terakreditasi [Internet]. 2020. [diakses 13 Mei 2020]. Tersedia pada: https:// persi.or.id/cegah-tenaga-kesehatan-tertularkemenkes-ingatkan-semua-apd-harus-lolos-ujilab-terakreditasi/

14. Amnesty International. Covid-19: Lindungi Tenaga Kesehatan, Penuhi APD dan Rapid Test [Internet]. 2020. [diakses 13 Mei 2020]. Tersedia pada: https://www.amnesty.id/covid19-lindungi-tenaga-kesehatan-penuhi-apd-danrapid-test/

15. Liputan6.com. Kemenkes: Tim Medis Meninggal Disebabkan APD yang Tidak Standar [Internet]. 2020. [diakses 13 Mei 2020]. Tersedia pada: https://www.liputan6.com/news/read/4230230/ kemenkes-tim-medis-meninggal-disebabkanapd-yang-tidak-standar

16. World Health Organization (WHO). Shortage of Personal Protective Equipment Endangering Health Workers Worldwide [Internet]. 2020. [diakses 6 Mei 2020]. Tersedia pada: https:// www.who.int/news/item/03-03-2020-shortageof-personal-protective-equipment-endangeringhealth-workers-worldwide

17. Inter-Agency Standing Committee (IASC). Catatan tentang Aspek Kesehatan Jiwa dan Psikososial Wabah COVID-19 Versi 1.0 [Internet]. 2020.[diakses 13 Mei 2020]. Tersedia pada: https://www.who.int/docs/ defaultsource/searo/indonesia/covid19/catatantentang-aspek-kesehatan-jiwa-dan-psikososialwabah-covid-19-feb-2020-indonesian . pdf?sfvrsn=ebae 5645_2

18. Liputan6.com. 7 Potret Memilukan Tenaga Medis Kelelahan Bekerja Hadapi Pasien Virus Corona, Ini Pesan Mereka [Internet]. 2020. [diakses 13 Mei 2020]. Tersedia pada: https:// www.liputan6.com/citizen6/read/4210412/7potret-memilukan-tenaga-medis-kelelahanbekerja-hadapi-pasien-virus-corona-ini-pesan- mereka

19. Kompas.com. Tentang Sewakul, Penolakan Jenazah Perawat Berujung Kecemasan [Internet]. 2020. [diakses 13 Mei 2020]. Tersedia pada: https://regional.kompas.com/ $\mathrm{read} / 2020 / 04 / 14 / 11010031 /$ tentang-sewakulpenolakan-jenazah-perawat-berujungkecemasan

20. Jansson M, Rello J. Mental health in healthcare workers and the Covid-19 pandemic era: Novel challenge for critical care. J Intensive Crit Care. 2020;6(2):6. doi: 10.36648/2471-8505.6.2.6

21. Lukman PR. Dampak Covid terhadap Kesehatan Mental Nakes: Hasil Pendampingan Tim Konseling RSCM. Webinar PERSI, 2020.

22. Kumparan. Respons IDI soal Kesanggupan Tenaga Medis Tangani Corona [Internet]. 2020. [diakses 14 Mei 2020]. Tersedia pada: https://kumparan.com/kumparannews/responsidi-soal-kesanggupan-tenaga-medis-tanganicorona-1tJDizJbvU0

23. Kompas. Menimbang Rasio Tenaga Medis Hadapi Covid-19 [Internet]. 2020. [diakses 13 Mei 2020]. Tersedia pada: https://kompas. $\mathrm{id} /$ baca/riset/2020/04/21/menimbang-rasiotenaga-medis-hadapi-covid-19/

24. Indonesia, BPPSDMK Kementerian Kesehatan. Sumber Daya Manusia Kesehatan dan Covid-19 [Internet]. 2020. [diakses 14 Mei 2020]. Tersedia pada: http://bppsdmk.kemkes.go.id/ web/content $/ 21 /$ kepadatan-tenaga-kesehatan

25. Indonesia, Setditjen Farmalkes Kementerian Kesehatan. Standar Alat Kesehatan Pelindung Diri (APD) dalam Manajemen Penanganan Covid-19 [Internet]. 2020. [diakses 28 April 2020]. Tersedia pada: https://farmalkes.kemkes. go.id/2020/04/ standar-alat-pelindung-diri-apddalam-manajemen-penanganan-covid-19/

26. Buse K, Mays N, Walt G. Making Health Policy. Second Edition. New York: Open University Press; 2012.

27. The Lancet. COVID-19: protecting health-care workers. Lancet. 2020; 395(10228): 922. doi: 10.1016/S0140-6736(20)30644-9

28. CNN Indonesia. Darurat Corona, Tito Akui Masih Ada Daerah Kekurangan APD [Internet]. 2020. [diakses 13 Mei 2020]. Tersedia pada: https://www.cnnindonesia. 
com/nasional/20200408095145-20-491503/ darurat-corona-tito-akui-masih-ada-daerahkekurangan-apd

29. Indonesia, Kementerian Perindustrian. Kemenperin Fokus Genjot Produktivitas Industri APD Nasional [Internet]. [diakses 13 Mei 2020]. Tersedia pada: https://kemenperin. go.id/artikel/21649/Kemenperin-Fokus-GenjotProduktivitas-Industri-APD-Nasional

30. Indonesia, Kementerian Kesehatan. Peraturan Menteri Kesehatan RI No. 7 Tahun 2020 tentang Perubahan atas Permenkes No. 51 Tahun 2014 tentang Pemasukan Alat Kesehatan Melalui Mekanisme Jalur Khusus Special Access Scheme.

31. Indonesia, Kementerian Kesehatan. Keputusan Menteri Kesehatan RI No. 218 Tahun 2020 tentang Alat Kesehatan, Alat Kesehatan Diagnostik In Vitro, dan Perbekalan Kesehatan Rumah Tanggayang Dikecualikan dariPerizinan Tata Niaga dalam Rangka Penanggulangan Coronavirus Disease 2019 (COVID-19).

32. Indonesia, FK-KMK Universitas Gadjah Mada. Twice Weekly Covid-19 Webinar: Pemenuhan APD dan Sustainabilitasnya [Internet]. 2020. [diakses 29 April 2020]. Tersedia pada: https:// fk.ugm.ac.id/twice-weekly-covid-19-webinarpemenuhan-apd-dan-sustanibilitasnya/

33. Katadata. Jumlah Produsen Alkes Melonjak saat Pandemi, Tertinggi APD 567\% [Internet]. 2020. [diakses 13 Mei 2020]. Tersedia pada: https://katadata.co.id/agungjatmiko/ berita/5e9a41f5b868a/jumlah-produsen-alkesmelonjak-saat-pandemi-tertinggi-apd-567

34. Indonesia, Ditjen Perimbangan Keuangan Kementerian Keuangan RI. FAQ terkait Kebijakan Relaksasi Penyaluran dan penggunaan Dana Bantuan Operasional Kesehatan (BOK) serta Pemberian Insentif bagi Tenaga Kesehatan (Nakes) Daerah [Internet]. 2020. [diunduh 30 April 2020]. Tersedia pada: http://www.djpk.kemenkeu.go.id/wp-content/ uploads/2020/04/FAQ-Kebijakan-BOKTambahan-Untuk-Tenaga-Kesehatan.pdf

35. Indonesia, Kementerian Kesehatan. Keputusan Menteri Kesehatan RI No. HK.01.07/ MENKES/278/2020 tentang Pemberian Insentif dan Santunan Kematian bagi Tenaga Kesehatan yang Menangani Coronavirus Disease 2019 (COVID-19).

36. Taiwan News. Taiwan to boost pay for frontline healthcare workers amid COVID-19 [Internet]. 2020. [diakses 11 Mei 2020]. Tersedia pada: https://www.taiwannews.com.tw/en/ news/3931168

37. CodeBlue. Covid-19 Frontline Health Workers Get Allowance Raise To RM600 Monthly [Internet]. 2020. [diakses 11 Mei 2020]. Tersedia pada: https://codeblue.galencentre. org/2020/03/27/covid-19-frontline-healthworkers-get-allowance-raise-to-rm600monthly/

38. Gentilini U, Almenfi M, Blomquist J, Dale P, Giuffra LDF, Desai V, et al. Social Protection and Jobs Responses to COVID-19: A Real-Time Review of Country Measures (May 8, 2020). (English).COVID-19Living Paper. Washington, DC: World Bank Group [diakses 11 Mei 2020]. Tersedia pada: http://documents.worldbank. org/curated/en/448321588971503966/SocialProtection-and-Jobs-

39. Indonesia, Kementerian Kesehatan. Surat Edaran Menteri Kesehatan RI No. HK.02.01/ MENKES/3030/2020tentangPenyelenggaraaan Pelayanan Kesehatan Melalui Pemanfaatan Teknologi Informasi dan Komunikasi dalam Rangka Pencegahan Penyebaran Coronavirus Disease 2019 (COVID-19).

40. Indonesia, Kementerian Kesehatan. Peraturan Menteri Kesehatan RI No. 20 tahun 2019 tentang Penyelenggaraan Pelayanan Telemedicine antar Fasilitas Pelayanan Kesehatan.

41. Hollander JE, Carr BG. Virtually Perfect? Telemedicine for Covid-19. $N$ Engl J Med. 2020;382(18):1679-1681. doi: 10.1056/ NEJMp2003539

42. socialprotection.org. Webinar COVID-19 Experience and Lessons: Country-to-Country Learning and South-South on April 302020. 2020.

43. Indonesia, Pusat Krisis Kesehatan Kementerian Kesehatan. Kemenkes Distribusikan Logistik Kesehatan untuk Penanganan COVID-19 [Internet]. 2020. [diakses 13 Mei 2020]. Tersedia pada: http://pusatkrisis.kemkes.go.id/ kemenkes-distribusikan-logistik-kesehatan- 
untuk-penanganan-covid-19

44. Indonesia, Biro Pers Media dan Informasi Sekretariat Presiden. Rapat Terbatas mengenai Optimalisasi Industri Dalam Negeri untuk Penanganan Covid-19 [Internet]. 2020. [diakses 6 Mei 2020]. Tersedia pada:https:// www.presidenri.go.id/transkrip/rapat-terbatasmengenai-optimalisasi-industri-dalam-negeriuntuk-penanganan-covid-19/

45. Indonesia, Undang-Undang No. 36 Tahun 2014 tentang Tenaga Kesehatan. 2014.

46. Indonesia, Gugus Tugas Percepatan Penangan Covid-19. Melalui Layanan Telemedicine, Masyarakat Tak Perlu ke Rumah Sakit [Internet]. 2020. [Internet]. 2020. [diakses 11 Mei 2020]. Tersedia pada: https://covid19.go.id/p/berita/ melalui-layanan-telemedicine-masyarakat-takperlu-ke-rumah-sakit

47. SehatQ. Telemedicine Membuat Dokter Bisa Menjangkau Pasien Hingga Pelosok [Internet]. 2020. [diakses 11 Mei 2020]. Tersedia pada: https://www.sehatq.com/artikel/telemedicinemembuat-dokter-bisa-menjangkau-pasienhingga-pelosok

48. Indonesia, Perhimpunan Rumah Sakit Seluruh Indonesia (PERSI). White Paper: Kesiapan Rumah Sakit Menghadapi Era Digitalisasi Menuju Smart Hospital 4.0 [Internet]. 2020. [diakses 11 Mei 2020]. Tersedia pada: https:// www.persi.or.id/118-adv/1221-white-paperkesiapan-rumah-sakit-menghadapi-eradigitalisasi-menuju-smart-hospital-4-0

49. Berita Satu. Siloam Melayani Telemedicine [Internet]. 2020. [diakses 12 Mei 2020]. Tersedia pada: https://www.beritasatu.com/ megapolitan/625525-caroline-riady-siloammelayani-telemedicine

50. Indonesia, Universitas Airlangga. RSUA Telemedicine, Inovasi Terbaru dari RS UNAIR [Internet]. 2020. [diakses 13 Mei 2020]. Tersedia pada: http://news.unair.ac.id/2017/02/08/rsuatelemedicine-inovasi-terbaru-rs-unair/ 